\title{
PERANCANGAN GROUP TECHNOLOGY LAYOUT DI PT DPS SURABAYA DENGAN METODE SIMULASI DAN TAGUCHI
}

\author{
RAHAJU SARASWATI, ALI AZHAR, MUDJAHIDIN, DAN DEDY KUNHADI \\ Jurusan Teknik Industri, Universitas WR. Supratman Surabaya \\ E-mail: rahayu_swati@gmail.com
}

\begin{abstract}
ABSTRAK
PT Dok and Perkapalan Surabaya (DPS) adalah salah satu BUMN strategis di bidang kelautan. Masalah yang dihadapi oleh PT DPS adalah untuk meningkatkan efisiensi sistem produksi. Pada penelitian ini desain proses produksi kapal dilakukan dengan metode Process Lane Construction and Zone Outfitting atau yang dikenal dengan istilah Group Technology Layout (Manufacturing Cell System) untuk mengatasi masalah inefisiensi pada proses produksi kapal di PT DPS. Proses desain dilakukan dengan mengintegrasikan metode Simulasi, Taguchi, Response Surface Methodology, dan AHP. Dari hasil penelitian dengan metode Taguchi dan Metodologi Response Surface diketahui bahwa dalam tata letak tahap fabrikasi yang optimal adalah tipe kedua, set optimal waktu adalah 40 menit, ukuran lot optimal adalah 16 ton, interval pemuatan optimal adalah 400 menit, stabilitas permintaan optimal adalah 92,5\%, di sub-perakitan tahap tata letak optimal adalah tipe pertama, set optimal waktu adalah 40 menit, lot size optimal adalah 10 ton, interval pemuatan optimal adalah 400 menit, stabilitas permintaan optimal adalah 92,5\%, dalam tata letak perakitan tahap optimal adalah tipe pertama, set optimal waktu adalah 40 menit, lot size optimal adalah 6 ton, interval pemuatan optimal adalah 400 menit, stabilitas permintaan optimal adalah 92,5\%, dalam tata letak ereksi tahap optimal adalah tipe kedua, set optimal waktu adalah 40 menit, ukuran lot optimal adalah 6 ton, interval pemuatan optimal adalah 480 menit, stabilitas permintaan optimal adalah $92,5 \%$.
\end{abstract}

Kata kunci: group technology layout, simulasi, taguchi, response surface methodology, analytical hierarchy process

\begin{abstract}
PT Dok and Perkapalan Surabaya (DPS) is one of several strategic BUMN in marine field. Problem that faced by PT DPS how to improve effisiency its production system. In this research ship production process design is done by using Process Lane Construction and Zone Outfitting method or it is known as Group Technology Layout (Manufacturing Cell System) term in order to solve inefficiency problem at ship production process in PT DPS. Design process is performed by integrating Simulation method, Taguchi, Response Surface Methodology, and Analytical Hierarchy Process (AHP). Taguchi method and Response Surface Methodology are used for experiment and optimization at manufacturing system. Research result with Taguchi method and Response Surface Methodology shows that in fabrication stage optimal layout is second tipe, optimal set up time is 40 minutes, optimal lot size is 16 tons, optimal loading interval is 400 minutes, optimal demand stability is $92.5 \%$, in sub-assembly stage optimal layout is first tipe, optimal set up time is 40 minutes, optimal lotsize is 10 tons, optimal loading interval is 400 minutes, optimal demand stability is $92.5 \%$, in assembly stage optimal layout is first tipe, optimal set up time is 40 minutes, optimal lotsize is 6 tons, optimal loading interval is 400 minutes, optimal demand stability is $92.5 \%$, in erection stage optimal layout is second tipe, optimal set up time is 40 minutes, optimal lot size is 6 tons, optimal loading interval is 480 minutes, optimal demand stability is $92.5 \%$.
\end{abstract}

Key words: group technology layout, simulation, taguchi, response surface methodology, analytical hierarchy process

\section{PENDAHULUAN}

PT. Dok dan Perkapalan Surabaya (Persero), yang mempunyai core business di bidang ship building, ship repair, dan ship conversion adalah perusahaan galangan kapal nasional yang sudah berstandar internasional dan telah berstandar ISO 9001 sejak 1997. Banyak tantangan yang harus dihadapi oleh industri galangan kapal nasional seperti PT Dok dan Perkapalan Surabaya (Persero) sekarang ini, seperti semakin berkembangnya galangan kapal yang berada (menuju) ke segmen pasar yang sama, berkembangnya galangan kapal di Philipina yang letak geografisnya berdekatan dengan Indonesia, keterbatasan penguasaan teknologi dan kualitas sumber daya manusia yang ada membuat PT DPS masih cukup sulit untuk berkompetisi di pasar global, kesulitan di dalam mengikuti tender dan memenuhi 
sistem pembayaran yang secara umum berlaku pada order internasional, sebagai akibat lemahnya pendanaan jangka panjang.

Untuk memproduksi kapal dengan harga yang murah, kualitas tinggi dan waktu pembangunan yang singkat dibutuhkan suatu sistem produksi yang mampu menciptakan efisiensi pada keseluruhan sistem produksi (Kuswanto, 2003). Group Technology layout adalah suatu metode pembangunan kapal yang mampu mengatasi masalah inefisiensi tersebut karena dengan aplikasi Group Technology Layout (GT layout) pada proses produksi kapal akan didapat beberapa manfaat yaitu total waktu yang dibutuhkan untuk mensetup mesin dapat dikurangi, proses pekerjaan menjadi lebih sederhana, lot size bisa dikurangi, work-in-process (WIP) inventory berkurang, manufacturing lead time lebih singkat, kepuasan hasil yang lebih tinggi, pengendalian manajemen yang lebih baik, karena responsibilitas berdasarkan produksi dan akuntabilitas yang berasal dari team performance (penampilan team) (Burbidge, 1975).

Penelitian ini bertujuan untuk merancang group technology layout (manufacturing cell system) pada proses produksi kapal di PT Dok dan Perkapalan Surabaya, melakukan perancangan dan pengembangan model simulasi Group Technology Layout dengan model simulasi ARENA (Wirabuana, dkk., 1999), melakukan eksperimen dan rekayasa kualitas sistem produksi kapal di PT Dok dan Perkapalan Surabaya dengan metode Taguchi (Fowlkes,1995) mengembangkan model optimasi sistem produksi kapal dengan metode Response Surface Methodology (RSM),dan memaksimalkan efisiensi Sistem produksi kapal di PT Dok dan Perkapalan Surabaya dengan meminimalkan mean work in process, mean waiting time, dan mean flow time (waste workshop).

\section{METODE}

Untuk melakukan penelitian ini diperlukan beberapa tahapan. Tahapan yang pertama adalah formulasi masalah dan melakukan perencanaan studi. Tahap yang kedua adalah mengumpulkan data untuk perancangan GT Layout. Tahap ketiga adalah perancangan GT Layout. Tahapan yang keempat adalah pembuatan model simulasi Group Technology Layout. Tahapan yang kelima adalah perancangan eksperimen dengan metode Taguchi dan penetapan level optimal dengan multivariate signal-to-noise ratio (Pease, 1993). Tahapan yang keenam adalah optimasi dengan RSM (Response Surface Methodology) dengan langkah-langkah yang meliputi pengukuran bobot performansi dengan metode AHP, eksplorasi RSM untuk perancangan tangguh (robust), pembentukan model matematis, penetapan solusi optimal (Chan dan Xiao, 1995). Tahapan ketujuh adalah analisis data output dan penarikan kesimpulan. Sedangkan tahapan yang terakhir adalah dokumentasi, presentasi dan implementasi.

\section{HASIL DAN PEMBAHASAN \\ Perancangan Group Technology Layout (Process Lanes Constructions and Zone Outfitting)}

Group technology adalah suatu filosofi atau konsep pemikiran dalam industri manufaktur yang mengidentifikasikan serta mencari kesamaan komponen yang diproduksi dalam proses pengerjaan maupun desain agar supaya dapat diambil keuntungan dari kesamaan dalam penggunaannya (Groover, 1987). Group technology di dalam menyelesaikan permasalahannya dimulai dengan pengelompokan komponen yang dihasilkan ke dalam sistem kodifikasi dari kesamaan karakteristik. Karakteristik yang dikelompokkan berhubungan dengan karakteristik perancangan desain dan proses pembuatannya. Sedangkan part family adalah kumpulan dari komponen yang mana masing-masing mempunyai kesamaan di dalam bentuk desain dan ukuran, atau kesamaan proses yang dikehendaki dalam pengerjaannya. Dari part family kemudian dapat dibentuk machine cell atau kelompok mesin yang dapat mengerjakan proses pengerjaan dari tiaptiap bentuk komponen dalam satu family.

Group Technology layout atau dalam bidang perkapalan lebih dikenal dengan istilah Process Lane Construction adalah suatu seri stasiun kerja yang dilengkapi dengan fasilitas produksi, seperti mesin, fasilitas, material, dan tenaga kerja yang terampil, untuk membentuk satu konstruksi yang mempunyai kesamaan bentuk dalam proses produksi. Hal ini merupakan pembagian proses produksi ke dalam problem area masing-masing. Kapal dalam pembagian blok-blok harus berpedoman pada problem area untuk mendukung process lane. Sebagai contoh blok-blok untuk daerah bagian tengah dasar ganda termasuk dalam kategori flat panel blocks, yaitu blok-blok yang jumlahnya cukup banyak dan proses assembly-nya mudah.

Berdasarkan konsep Group Technology Layout, analisa terhadap aliran proses produksi serta berdasarkan pertimbangan fasilitas dan sumber daya yang dimiliki PT Dok dan Perkapalan Surabaya, maka sistem produksi kapal di PT Dok dan Perkapalan Surabaya dapat dirancang menjadi manufacturing cell system atau process lane construction berdasarkan beberapa kriteria, yaitu tahapan proses produksi, kesamaan karakteristik 
pada produk antara sehingga bisa dikelompokkan dalam beberapa part family, dan berdasarkan zona konstruksi. Berdasarkan kriteria-kriteria tersebut Process lanes Construction (GT Layout) di PT Dok dan Perkapalan Surabaya dapat dibagi menjadi beberapa bagian, yaitu process lane untuk tahap fabrikasi yang memproduksi beberapa part family. Pertama, Internal parts from plate (termasuk penetration) atau Parts and Pieces of Plate yang diproses pada Machine Cell 1. Kedua, Parallel Edge Parts (Skin and Panel Plates) yang diproses pada Machine Cell 2. Ketiga, Curved Parts (Bent Plates) yang diproses pada Machine Cell 3. Keempat, Shapes (Miscellaneous Operation) yang diproses pada Machine Cell 4. Dan yang kelima adalah Pipe Equipment yang diproses secara parallel dan simultan dengan setiap Machine Cell tersebut. Process lane untuk tahap sub-assembly memproses part family internal structure from flat panel yang diproses pada Machine Cell 1, internal structure from curved panel yang diproses pada Machine Cell 2, pipe assembly (welding process) yang diproses secara parallel dan simultan dengan machine cell-machine cell tersebut. Process lane untuk flat - block assembly memproses part family Curved Block yang diproses pada Machine Cell 1, Flat Panel/Block yang diproses pada Machine Cell 2. Process lane untuk erection, proses ini termasuk dalam aliran virtual work flow.

\section{Pengembangan Model Simulasi ARENA}

Kajian simulasi terhadap perilaku sistem berkembang dengan pesat sejalan dengan perkembangan teknologi komputer. Dewasa ini simulasi banyak dilaksanakan dengan bantuan komputer. Program komputer untuk simulasi dapat dikembangkan dengan menggunakan General Purpose Language seperti Fortran, Pascal, C; atau dikembangkan dengan menggunakan Simulation Language seperti SIMAN (Simulation Analysis), SLAM (Simulation language for Alternative Modelling), GPSS (General Purpose Simulation System), SIMSCRIPT, ARENA dan lain-lain. Simulasi juga bisa dilakukan dengan memanfaatkan paket program komersial yang dibuat untuk kajian simulasi dimana user memerlukan sedikit pengetahuan tentang pemrograman. Paket program semacam itu misalnya Promodel, SIM FACTORY, WITNESS, Excell + .

Langkah awal yang harus dilakukan dalam pengembangan model simulasi Group Technology Layout dalam penelitian ini adalah memahami sistem manufaktur yang ada sehingga pada nantinya gambaran sistem tersebut dapat dituangkan dalam model. Setelah model yang dibuat dan diteliti, langkah selanjutnya adalah mentransfer model tersebut ke dalam software ARENA. Dalam ARENA ada beberapa modul, yaitu modul arrive, server, maupun inspect yang harus diisi.

Model simulasi untuk group technology layout (process lanes) untuk tahap fabrikasi dapat dilihat pada gambar 1. Model simulasi tersebut dikembangkan dengan software ARENA dengan SIMAN Summary Report. Input dari model simulasi tersebut adalah 1) waktu antar kedatangan dari part family yang meliputi Internal parts from plate (termasuk penetration) atau Parts and Pieces of Plate, Parallel Edge Parts (Skin and Panel Plates), Curved Parts (Bent Plates), Shapes (Miscellaneous Operation), dan Pipe Equipment untuk tahap fabrikasi; waktu antar kedatangan internal structure from flat panel, enternal structure from curved panel, Pipe assembly (welding process) untuk tahap sub-assembly; waktu antar kedatangan dari Curved Block, Flat Panel/ Block untuk tahap assembly. 2) Waktu proses pada tiap tahap proses produksi kapal 3) Waktu set up 4) Lot size pembebanan ke setiap machine cell 5) Mean Time Between Failure (MTBF), Mean Time to Repair (MTTR), dan Demand Stability.

Model simulasi GT layout yang dirancang dengan software ARENA tersebut digunakan untuk mentukan process lane (GT Layout), waktu set up, loading interval, lot size, dan demand stability yang optimal. Penentuan kondisi optimal tersebut didasarkan pada kriteria mean waiting time, mean flow time, dan mean work in process yang paling minimal. Dengan ditentukannya nilai yang optimal dari variabel-variabel yang berpengaruh signifikan terhadap kinerja proses produksi kapal di PT Dok dan Perkapalan Surabaya, maka diharapkan akan terjadi peningkatan efisiensi proses produksi kapal di PT Dok dan Perkapalan Surabaya, karena waste work shop yang terjadi bisa diminimalkan.

\section{Rancangan Eksperimen dengan Metode Taguchi (Robust Design)}

Metode Taguchi bertujuan untuk mengoptimalkan perancangan produk atau proses agar dihasilkan suatu produk atau proses yang tangguh (robust). Hal ini berarti menentukan arsitektur terbaik dan level optimal dari faktor kendali. Untuk menentukan rancangan Group Technology Layout dan faktor kendali (waktu set up optimal, lot size optimal, loading interval optimal, dan demand stability yang optimal) pada tahap awal ini dilakukan eksperimen dengan metode Taguchi. Untuk melakukan eksperimen dengan Taguchi diperlukan data-data besarnya nilai faktor terkendali beserta levelnya, besarnya nilai faktor noise beserta levelnya, dan besarnya nilai respons.

Nilai faktor kendali dan faktor noise ditetapkan berdasarkan pengalaman, rujukan, keterangan serta 
pertimbangan yang diberikan oleh pihak proses engineering dari PT Dok dan Perkapalan Surabaya. Besarnya nilai respons meliputi mean flow time, mean waiting time, dan mean work in process didapatkan dari hasil eksperimen dengan model simulasi Group Technology Layout.

Untuk melakukan eksperimen dengan metode Taguchi ini digunakan rancangan eksperimen produk langsung dari Orthogonal Array $\mathrm{L}_{27}\left(3^{13}\right)$ dan juga $\mathrm{L}_{4}\left(2^{2}\right)$. Untuk menentukan level optimal dari masing-masing faktor kendali dilakukan perhitungan signal-to-noise ratio dari masing-masing level faktor. Perhitungan signal-to-noise ratio dilakukan dengan menggunakan rumus SNR untuk multivariate dengan kriteria smaller the better. Faktor kontrol optimal untuk setiap tahap proses produksi kapal hasil dari eksperimen dengan menggunakan metode Taguchi ada pada Tabel 1.

Tabel 1. Faktor kontrol optimal berdasarkan Eksperimen Taguchi

\begin{tabular}{lcrccl}
\hline \multirow{2}{*}{ Tahap } & \multicolumn{5}{c}{ Faktor Kontrol } \\
\cline { 2 - 6 } & A & B & C & D & E \\
\hline Fabrikasi & 60 menit & 18 ton & 360 menit & $95 \%$ & Tipe II \\
Sub-assembly & 60 menit & 10 ton & 360 menit & $95 \%$ & Tipe I \\
Assembly & 30 menit & 6 ton & 360 menit & $95 \%$ & Tipe I \\
Erection & 30 menit & 6 ton & 360 menit & $95 \%$ & Tipe II \\
\hline
\end{tabular}

\section{Perancangan Eksperimen dengan Metode Respons Surface}

Untuk menyelesaikan respons multi criteria dalam response surface methodology pada penelitian ini digunakan analytical hierarchy process (AHP).

Jadi A weighted performance measure (WPM) pada penelitian ini digunakan untuk mengevaluasi kombinasi banyak respons menjadi respons tunggal dengan menggunakan AHP seperti yang terlihat pada Tabel 2 .

\section{Pengembangan suatu matrik perbandingan berpasangan}

Tabel 2. Estimasi bobot untuk setiap kriteria performansi

\begin{tabular}{lccc}
\hline & Flow T & Waiting T & WIP \\
\hline Flow T & 1 & $1 / 4$ & 4 \\
Waiting T & 4 & 1 & 6 \\
WIP & $1 / 4$ & $1 / 6$ & 1 \\
\hline
\end{tabular}

Catatan: Nilai dari baris i dan kolom j adalah pengukuran dari eveluasi komponen preferensi, di mana baris i dibandingkan dengan kolom j

\section{Evaluasi judgement}

Tabel 3. Penjumlahan nilai setiap kolom

\begin{tabular}{lccr}
\hline & Flow T & Waiting T & WIP \\
\hline Flow T & 1 & $1 / 4$ & 4 \\
Waiting T & 4 & 1 & 6 \\
WIP & $1 / 4$ & $1 / 6$ & 1 \\
\hline Total & $\mathbf{2 1 / 4}$ & $\mathbf{1 7 / 1 2}$ & $\mathbf{1 1}$ \\
\hline
\end{tabular}

Tabel 4. Pembagian setiap kolom dengan total kolom

\begin{tabular}{lccc}
\hline & Flow T & Waiting T & WIP \\
\hline Flow T & $4 / 21$ & $12 / 68$ & $4 / 11$ \\
Waiting T & $16 / 21$ & $12 / 17$ & $6 / 11$ \\
WIP & $4 / 84$ & $12 / 102$ & $1 / 11$ \\
\hline
\end{tabular}

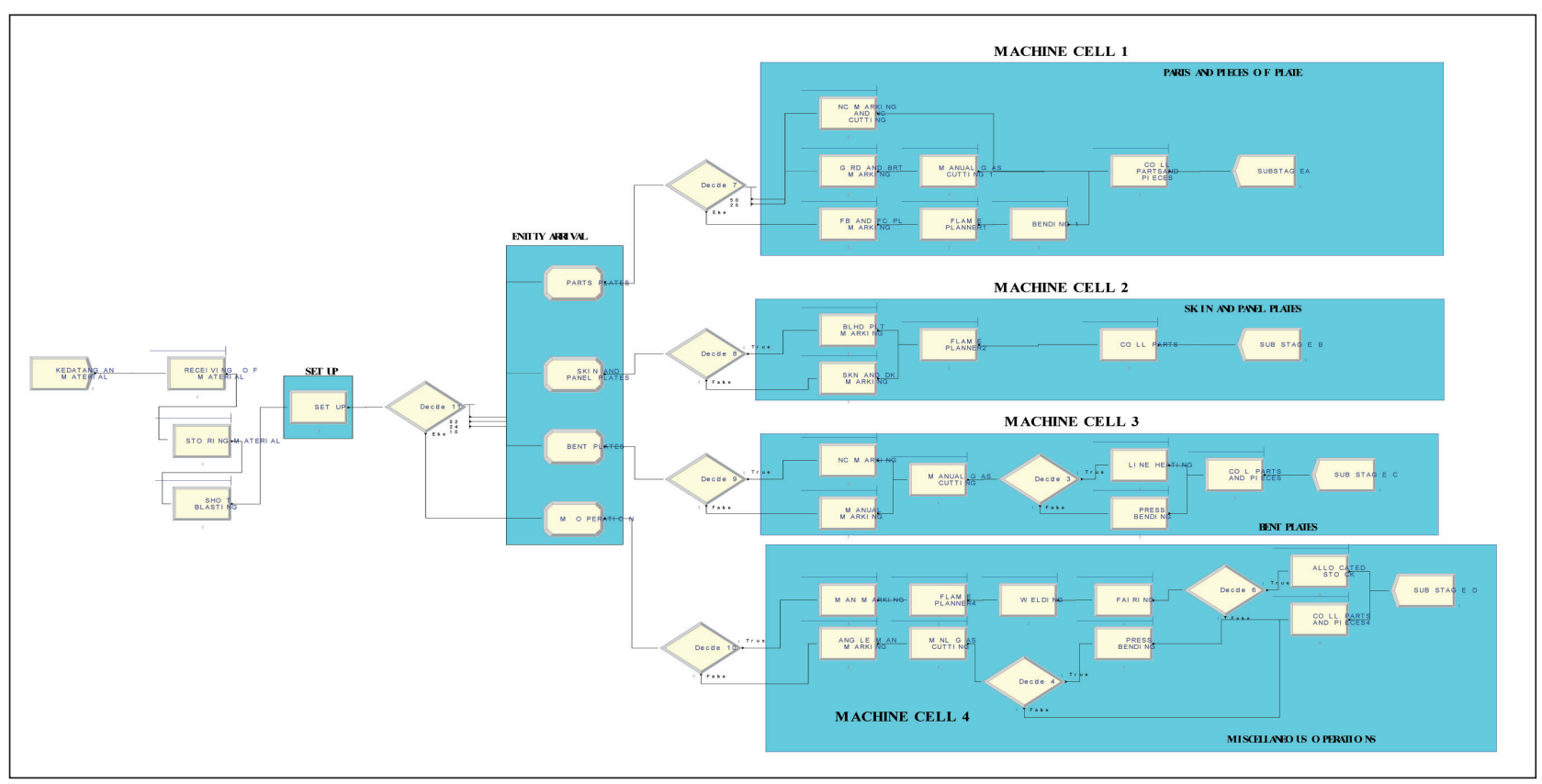

Gambar 1. Process Lanes (GT Layout) untuk tahap fabrikasi (Tipe 1) 
Tabel 5. Perhitungan rata-rata setiap baris

\begin{tabular}{lcccc}
\hline & Flow T & Waiting T & WIP & weight, $\boldsymbol{w}_{\perp}$ \\
\hline Flow T & $4 / 21$ & $12 / 68$ & $4 / 11$ & 0,24 \\
Waiting T & $16 / 21$ & $12 / 17$ & $6 / 11$ & 0.67 \\
WIP & $4 / 84$ & $12 / 102$ & $1 / 11$ & 0,09 \\
\hline
\end{tabular}

Dari penyelesaian dengan metode AHP di atas dapat diketahui bobot untuk kriteria waiting time adalah 0,67; flow time 0,24, dan Work in Process 0,09 . Bobot setiap kriteria yang dihasilkan dari metode AHP tersebut dikalikan dengan respons masing-masing kriteria akan menjadi $A$ weighted performance measure (WPM). Untuk lebih jelasnya lihat rancangan eksperimen dengan rancangan komposit pusat (Central Composite Design) (CCD) pada tabel 3 .

Tabel 6. Rancangan Komposit Pusat (Central Composite Design) (CCD)

\begin{tabular}{|c|c|c|c|c|c|}
\hline \multirow[b]{2}{*}{ Perlakuan } & \multirow[b]{2}{*}{$\mathbf{X}_{1} \mathbf{X}_{2} \mathbf{X}_{3} \mathbf{X}_{4}$} & \multicolumn{3}{|c|}{$\begin{array}{c}\mathbf{n} \mathbf{p} \\
\mathbf{L}_{\mathrm{ik}}=\sum \sum\left(\mathbf{Y}_{\mathrm{ijk} \mathbf{l} \mathbf{l})}{ }^{2}\right. \\
\mathbf{i}=\mathbf{1} \mathbf{l}=\mathbf{1} \\
\mathbf{n} \mathbf{x} \mathbf{p}\end{array}$} & \multirow[t]{2}{*}{$\mathbf{W P M}_{\mathrm{i}=} \sum_{\mathbf{x} \mathbf{L}_{\mathrm{ik}}}^{\sum \mathbf{W}_{\mathbf{k}}}$} \\
\hline & & $\mathrm{L}_{1.1}$ & $\mathrm{~L}_{1.2}$ & $\mathbf{L}_{1.3}$ & \\
\hline 1. & $-1-1-1-1$ & 500 & 764 & 250 & 654 \\
\hline 2. & $-1-1-11$ & 679 & 785 & 350 & 720 \\
\hline 3. & $\begin{array}{llll}-1 & -1 & 1 & -1\end{array}$ & 520 & 800 & 200 & 679 \\
\hline 4. & $-1-111$ & 760 & 1002 & 425 & 892 \\
\hline 5. & $-11-1-1$ & 520 & 709 & 300 & 627 \\
\hline 6. & $-11-11$ & 654 & 1200 & 600 & 1015 \\
\hline 7. & $-111-1$ & 432 & 1200 & 450 & 948 \\
\hline 8. & -1111 & 1232 & 1800 & 500 & 1547 \\
\hline 9. & $1-1-1-1$ & 650 & 880 & 468 & 788 \\
\hline 10. & $1-1-11$ & 900 & 2200 & 543 & 1739 \\
\hline 11. & $1-11-1$ & 1100 & 2200 & 643 & 1796 \\
\hline 12. & $1-111$ & 1650 & 7500 & 958 & 5507 \\
\hline 13. & $11-1-1$ & 954 & 1380 & 400 & 1190 \\
\hline 14. & $11-11$ & 3576 & 5010 & 860 & 4292 \\
\hline 15. & $111-1$ & 1503 & 15400 & 486 & 10722 \\
\hline 16. & 1111 & 2300 & 17200 & 890 & 12156 \\
\hline 17. & 0000 & 786 & 1675 & 560 & 1361 \\
\hline 18. & 0000 & 786 & 1675 & 560 & 1361 \\
\hline 19. & 0000 & 786 & 1675 & 560 & 1361 \\
\hline 20. & 0000 & 786 & 1675 & 560 & 1361 \\
\hline 21. & 0000 & 786 & 1675 & 560 & 1361 \\
\hline 22. & 0000 & 786 & 1675 & 560 & 1361 \\
\hline 23. & 0000 & 786 & 1675 & 560 & 1361 \\
\hline 24. & 0000 & 786 & 1675 & 560 & 1361 \\
\hline 25. & -20000 & 468 & 876 & 250 & 722 \\
\hline 26. & 2000 & 2122 & 4208 & 600 & 3383 \\
\hline 27. & $0-200$ & 145 & 700 & 90 & 512 \\
\hline 28. & 0200 & 16854 & 15001 & 800 & 14168 \\
\hline 29. & $00-20$ & 132 & 654 & 102 & 479 \\
\hline 30. & 0020 & 18786 & 17565 & 402 & 16313 \\
\hline 31. & $\begin{array}{lllll}0 & 0 & 0 & -2\end{array}$ & 905 & 490 & 234 & 566 \\
\hline 32. & 0002 & 3600 & 9025 & 3136 & 7193 \\
\hline
\end{tabular}

\section{Penentuan Group Technology Layout dengan Kondisi Operasi Optimal}

Kondisi operasi optimal akan diperoleh bila semua turunan parsial dari model matematis yang diduga sama dengan nol. Proses optimasi dilakukan dengan software MINITAB 14, dan kondisi operasi optimum untuk GT Layout pada tahap fabrikasi untuk keempat variabel kontrol di atas adalah sebagai berikut:

$\mathrm{X}_{1}$ (Waktu Set up) dengan level faktor $-2=40$ menit $\mathrm{X}_{2}$ (Lot Size) dengan level faktor $-1=16$ ton

$\mathrm{X}_{3}$ (Loading Interval) dengan level faktor $1=400$ menit

$\mathrm{X}_{4}$ (Demand Stability) dengan level faktor $-2=$ $92,5 \%$

Dari hasil optimasi dengan Response Surface Methodology diketahui bahwa pada tahap fabrikasi layout optimal adalah Tipe II, waktu set up optimal 40 menit, lot size optimal 16 ton, loading interval optimal 400 menit, demand stability optimal 92,5\%, pada tahap sub assembly layout optimal adalah Tipe I, waktu set up optimal 40 menit, lot size optimal 10 ton, loading interval optimal 400 menit, demand stability optimal 92,5\%, pada tahap assembly layout optimal adalah Tipe I, waktu set up optimal 40 menit, lot size optimal 6 ton, loading interval optimal 400 menit, demand stability optimal 92,5\%, dan pada tahap erection layout optimal adalah Tipe II, waktu set up optimal 40 menit, lot size optimal 6 ton, loading interval optimal 480 menit, demand stability optimal 92,5\%. GT Layout dengan kondisi operasi optimal untuk tahap fabrikasi dapat dilihat pada gambar 2 .

\section{SIMPULAN}

Dari hasil pengamatan dan penelitian tentang Perancangan Group Technology Layout pada proses produksi kapal di PT. Dok dan Perkapalan Surabaya (Persero) bisa diambil beberapa kesimpulan antara lain sebagai berikut. Berdasarkan kriteria-kriteria tahapan proses produksi, kesamaan karakteristik produk dan berdasarkan zone konstruksi, process lanes construction (GT Layout) di PT Dok dan Perkapalan Surabaya dapat dibagi menjadi beberapa bagian, yaitu process lane untuk tahap fabrikasi (dengan part family: internal parts from plate, Parallel Edge Parts, Curved Parts, Miscellaneous Operation, Pipe Equipment), process lane untuk tahap sub-assembly (yang memproses part family, internal structure from flat panel, Internal structure from curved panel, dan pipe assembly), dan Process lane untuk block assembly (memproses part family Curved Block dan Flat Panel/Block) Untuk menganalisa kinerja dari group technology layout yang dirancang 


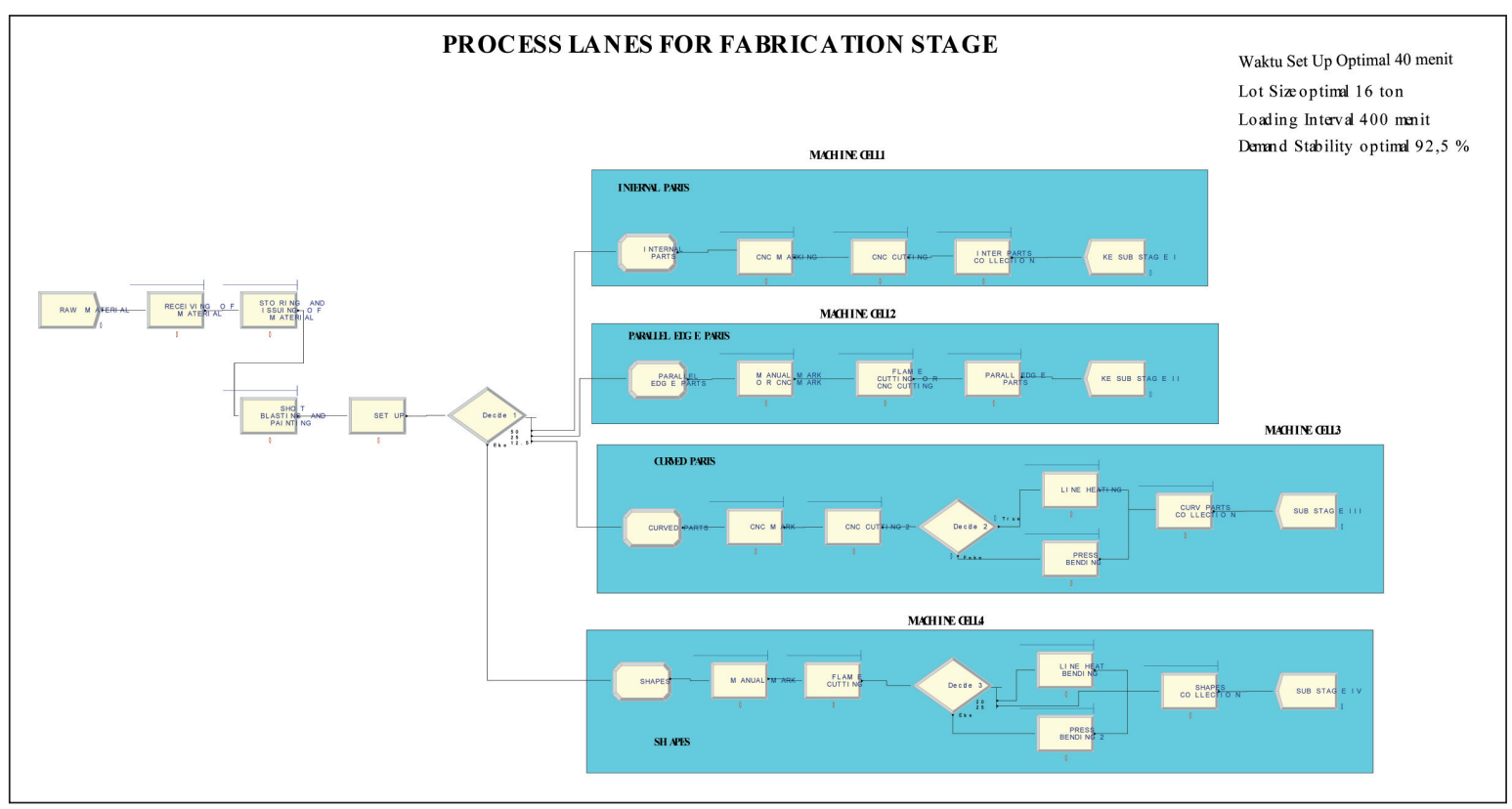

Gambar 2. GT Layout pada tahap fabrikasi dengan kondisi operasi optimal

tersebut dikembangkan model simulasi dengan software simulation language ARENA. Dalam ARENA ada beberapa modul, modul create/arrive, process/server, dispose, maupun inspect yang akan digunakan dalam pembuatan model simulasi. Pada penelitian ini dikembangkan model simulasi untuk process lanes pada tahap fabrikasi, sub-assemby, assembly, dan erection, dengan masing-masing mempunyai tiga tipe (disebut level pada desain eksperimen Taguchi). Dari Hasil Eksperimen dengan metode Taguchi dan Response Surface Methodology diketahui bahwa pada tahap fabrikasi layout optimal adalah Tipe II, waktu set up optimal 40 menit, lot size optimal 16 ton, loading interval optimal 400 menit, demand stability optimal 92,5\%, pada tahap sub assembly layout optimal adalah Tipe I, waktu set up optimal 40 menit, lot size optimal 10 ton, loading interval optimal 400 menit, demand stability optimal $92,5 \%$, pada tahap assembly layout optimal adalah Tipe I, waktu set up optimal 40 menit, lot size optimal 6 ton, loading interval optimal 400 menit, demand stability optimal 92,5\%, dan pada tahap erection layout optimal adalah Tipe II, waktu set up optimal 40 menit, lot size optimal 6 ton, loading interval optimal 480 menit, demand stability optimal 92,5\%. Karena desain dan manufaktur merupakan pilar bagi usaha galangan kapal, maka penerapan Group Technology Layout sangat penting untuk dilaksanakan di sistem manufaktur PT Dok dan Perkapalan Surabaya. Karena dengan diterapkkannya Group Technology layout di PT Dok dan Perkapalan Surabaya, bisa menciptakan efisiensi sistem secara keseluruhan dan pengendalian manajemen yang lebih baik di perusahaan tersebut. Dengan sistem manufaktur yang sangat efisien dan manajemen yang terkontrol dengan baik, maka kualitas proses produksi kapal di PT Dok dan Perkapalan Surabaya dengan sendirinya akan meningkat pula.

\section{DAFTAR PUSTAKA}

Burbidge, J.L., 1975. The Introduction of Group Technology, William Heineman, London.

Chan, L.K. dan Xiao, PH., 1995 Combined robust design. Manitoba: Marcel Dekker and ASQC.

Fowlkes, William Y dan Creveling, Clyde M., 1995. Engineering Methods for Robust Product Design: Using Taguchi Methods in Technology and Product Development, New York; Addison - Wesley Publishing company.

Groover, M.P., 1987. Automition Production Systems and Computer Integrated Manufacturing, PrenticeHall.

Kuswanto A, 2003. Penerapan Japanese Ship Building Quality Standard (JSQS) pada Proses Pembangunan Kapal Tanker 6500 DWT di PT Dok dan Perkapalan Surabaya, Tugas Akhir Perkapalan ITS Surabaya.

Peace G.S., 1993. Paguchi Methods a Hands on Approach. New York Addison Wesley Publishing Company.

Peace GS., 1993. Taguchi Methods a Hands on Approach. New York Addison - Wesley Publishing Company.

Wirabhuana A, Hari Purnomo, Luqman Hakim, 1999, Simulasi dan Pengaplikasiannya dalam Perangkat Lunak: Suatu Gambaran Umum, TEKNOIN Nomor 9 Tahun IV, UII. 